\title{
Computed tomography log scanning - high technology for forestry and forest based industry
}

\author{
Tomáš Gergel ${ }^{1 *}$, Tomáš Bucha ${ }^{1}$, Miloš Gejdoš², Zuzana Vyhnáliková2 \\ ${ }^{1}$ National Forest Centre - Forest Research Institute Zvolen, T. G. Masaryka 2175/22, SK - 96092 Zvolen, Slovak Republic \\ ${ }^{2}$ Technical University in Zvolen, Faculty of Forestry, The Institute of Foreign Languages, T. G. Masaryka 24, \\ SK-96053 Zvolen, Slovak Republic
}

\begin{abstract}
Heterogeneity in the tree trunks' shapes and quality is not often reached fully using raw material potential in grading processes of tree and stand and the following sawmill processing.

Therefore, optimization of given processes is a current topic of research and is part of the operational practice. In the contribution we submit a survey of solving the given problems in the European and Slovak conditions. A significant impulse for solving problem at a new level is a significant progress in the field of industrial computed tomography. New and fast CT scanners have been developed and they enable to increase valuation by $15 \%$ in coniferous trees and by $24 \%$ in broadleaf trees. In the contribution we analyze period of returns of CT scanner's implementation into the sawmill process within Slovak context for small, medium-sized and big sawmills. Results show that period of returns for big sawmills is approximately for years, for medium-sized sawmills is eight years when processing coniferous softwood or three to eight years in case of broadleaved processing. In the final synthesis we present a concept of interlinking the 3D scanner and technologies of laser woodcutting with the outcomes allowing to optimize stand grading and maximize profit of the given raw wood in the sawmill processing.
\end{abstract}

Key words: CT scanner; sawmill; sawing optimisation; log; profit

Editor: Miloš Pánek

\section{Introduction}

Effective utilization and reproduction of renewable sources including raw wood material is an essential component of successful transformation of society from fossil economy to green economy.

One of the research areas that provide knowledge needed for optimal valuation of raw wood material is the detection of quality and quality wood properties. There are a lot of defectoscopic apparatuses working on different physical principles. The latest technological news is a development and implementation of three-dimensional (3D) computed tomography (CT) of scanners.

The aim of the contribution is: a) in the analytical part to describe a current state of knowledge in the sphere of tree and stand grading, to analyze potential of benefits and a possibility to use $3 \mathrm{D}$ scanner in grading and sawmill wood-processing, to summarize economic benefits of the introduction of CT-scanner for round wood processing industry; b) in the synthetically part there is presented a new concept of introduction and application of $3 \mathrm{~d}$ CT scanner in forestry-wood processing complex and on the basis of a model is derived a period of returns of investment in the CT scanner in the Slovak conditions.

\section{Contemporary issues in the selection of trees and forest cover abroad and in Slovakia}

\subsection{Selection of trees and forest cover}

As well as the quantity of trees produced, their quality is also of utmost importance. Wood of higher quality is more expensive, has higher utility value and greater value added. Production research in the area of forestry throughout the world has been intensively studying the issue of produced wood quality since the 1960s. The first assortment tables were published for poplar clones in Hungary (Kulcsar 1965), a methodical description of assortment procedures in relation to value production (Sterba 1983) and assortment tables for beeches (Kleine 1986) in Austria, and for beeches and oaks in 
the Czech Republic (Pařez 1987). More contemporary research studies include studies on assortment structure in Serbia (Danilović \& Janjatović 2005) and assortment yield tables for oaks in the lower Volga region in Russia (Chernykh et al. 2014). The need for national or even regional approaches emerged from the variability of stand characteristics and growth conditions as well as genotypic and phenotypic, shape and qualitative characteristics of trees and forest cover, or rather of wood defects.

There are two basic principles in the process of woodquality modelling: 1 . solid geometry, which simulates a requested assortment structure based on the partial results according to length and diameter of logs and distribution of external and internal features of woodquality in its longitudinal profile, 2. empirical sorting model, i.e. wood-quality is defined directly from the tree samples during the yielding and manipulation processes and its mathematical models are constructed according to the acquired results. Both approaches were analysed by Petráš \& Nociar (1991). According to their study the empirical sorting model has been used in Slovakia ever since. This model was developed as part of the forestry production research in Slovakia, which also included the issue of produced wood quality. On the basis of empirical material measured in the direct assortment process, models used to develop stand assortment tables for trees and forest covers for 8 economically significant trees were designed. Specifically: spruces, firs, pines, oaks, beeches (Petráš \& Nociar 1991) as well as larches, hornbeams, birches and poplar clones Robusta and I-214 (Mecko et al. 1993; Mecko et al. 1994; Petráš et al. 2007). Combined with production models of yield tables (Halaj 1990) their models were used to design assortment yield tables (Petráš et al.1996) and connection with the price of wood and yielding costs as well as for models of value production (Halaj 1990).

Practical methods of qualitative inventorying are usually based on the selective approach, ocular assessment of dimensional and qualitative characteristics of logs as well as of the tree's age. On this basis and on the basis of assortment tables, the forest cover is divided into individual assortments. Inventorying of trees provides the distribution of trees (in $\mathrm{m}^{3}$, shares in \%) into assortments.

Assortment accuracy of trees is shown in (Table 1). Accuracy of the models is based on the analysis of deviations between actual shares of assortments within experimental areas and shares provided by the models derived. In general it can be concluded that the accuracy of assortment models is relatively low-mainly because of very inaccurate estimation of internal wood defects that are estimated from external features.

In the last decade the research in the area of quality accuracy has been stagnating. One of the reasons why is that except for the basic parameters of models - tree thickness, quality and damage of logs - no other significant and effective factors that could improve the accuracy of models were determined.

Internal wood defects caused by biotic factors, mainly fungi, pose another problem of tree assortment. In standing trees, it is possible to take them into account only on the basis of external characteristics of logs and characteristics indicating presence of biotic organisms, e. g. sporocarps (fungi). For research purposes, not only ocular detection of internal wood defects and practical assessment of condition of valuable trees mainly within the territory of built-up areas and botanical gardens is used, but there are also ultrasound decay detectors of tree hollows, e. g. Arbotom 3D Pack (Rinntech e.K.) or ArboSonic 3D (Fakopp Enterprise). However, such detectors have not been used in forestry because of the economic inefficiency of the method which has relatively high time demands.

\subsection{Wood quality and detection of defects}

Wood quality research in the wood-processing industry has been so far separated from forestry research. In wood storehouses, logs are usually damaged mainly because of inappropriate storing conditions. The most common defects are: drying, formation of cracks, wood-destroying fungi, ligniperdus insects, undesirable odour of wood and photosynthetic degradation. Types of wood degradation and methods of protection are comprehensively dealt with e.g. by Hoadley (2000). The latest research initiative on a European level that deals with the issue of wood quality and wood products was the COST Action E53 in 2006-2010 focusing on:

- scanning of stems and logs for quality assessment of geometrical and qualitative characteristics,

- moisture content and distortion determination,

- strength, stiffness and appearance grading of wooden products.

Although the project proved to be of great importance, there has not yet been created a specialized workplace within the Visegrád Group of countries that would systematically and comprehensively address the issue of wood defect detection using scanning technology and 3D models.

There have been several research studies regarding quality and defects of raw wood assortments and their

Table 1. Accuracy of assortment process - the range depends on the quality trade (of assortments).

\begin{tabular}{|c|c|c|c|c|c|}
\hline \multirow{2}{*}{ Tree species } & \multicolumn{2}{|c|}{ Assortments tables } & \multirow{2}{*}{ Tree species } & \multicolumn{2}{|c|}{ Assortments tables } \\
\hline & Tree & Growing & & Tree & Growing \\
\hline Spruce & $20-34 \%$ & o 1 until 2\% bigger & Beech & $20-78 \%$ & - \\
\hline Fir & $32-43 \%$ & - & Hornbeam & $13-22 \%$ & o 1 until $3 \%$ \\
\hline Pine & $21-35 \%$ & - & Birch & $10-33 \%$ & - \\
\hline Larch & $21-27 \%$ & - & Poplar-I 214 & $15-51 \%$ & - \\
\hline Oak & $17-28 \%$ & o 1 until $8 \%$ bigger & Poplar - Robusta & $12-27 \%$ & - \\
\hline Beech & $24-37 \%$ & - & - & - & - \\
\hline
\end{tabular}


connection to the production process, as well as the relationships between wood quality - raw material assessment - and marketing and wood trade. Some results can be found in the following publications (Mahút \& Réh 1995; Greppel et al. 2009; Klement et al. 2010; Suchomel \& Gejdoš 2013).

Wood defects scanning is e.g. dealt with by the WEINIG Group in Tauberbischofsheim (Germany), Microtec CT (Italy) and WoodEye AB (Sweden). These companies develop commercial scanners such as the CombiScan + C, Microtec CT and WoodEye 5 with the following basic characteristics:

The WoodEye 5 scans all four sides of the lumber in both axes, which provides additional information about the space between growth rings, pith position and knot structures. Scanning is based on multi-spectral and laser technology. Rontgen technology is adjustable.

The CombiScan $+C$ scans surface by four-sided laser cameras. Other detecting equipment (colour camera, Rontgen technology, moisture determination) is adjustable. Software enables detection of a wide scale of wood defects in real time.

The Microtec CT Log $360^{\circ}$ CT X-ray scans and digitally reconstructs internal characteristics of logs. This enables selection of the optimal cutting solution in real time. The scanner provides smooth, high-quality and full-3D $\log$ reconstruction; therefore size and location of internal wood defects can be seen in all three dimensions.

The variable software and hardware capabilities of these scanners represent the best technology in the area of defects detection and raw material assessment.

\subsection{Cutting plans and profit optimization}

The issue of cutting plans has been the subject of longterm research. As well as mathematical techniques there are also various software applications. Complex solutions are generally provided with the aforementioned scanning devices or as separate commercial products (e.g. Optimik, available at www.rksoft.sk/optimik.php). Contemporary solutions depend on the cutting technologies used, i.e. circular saws, bow saws or band saws.

One ground-breaking technology is laser cutting (Biatec Laser technology s.r.o.) which is challenging and creating new ideas aiming to optimize cutting plans. This technology constitutes a new modern research based approach and its mastering requires creation of an interdisciplinary team consisting of timber industry specialists and forestry specialists in the area of wood defects detection, as well as a specialist in the area of mathematical modelling, imaging (scans) and production process modelling.

Up to this date, combination of forestry and timber industry research in the area of wood quality has been marginal and inhomogeneous. It is a global challenge for the forestry-timber industry. Information and communication technology provides techniques connect- ing evidence and supply systems of forestry with the systems of wood-processing and of the timber industry and therefore enabling management of anticipated production according to assortments supplied with actual production of wood products. An important role in this interconnecting process is provided by $3 \mathrm{D}$ scanning technologies of logs and 2D scanning of timber before processing wood into final products (www.lignosilva. nlcsk.org/files/Science_Business_summit.pdf).

\section{Review on current status of $\log$ CT scanning}

\subsection{CT Log Scanner}

CT scanners are the most advanced technology used for detection of internal wood defects. They work on the same principle as computed tomography scanners used in medicine. In terms of parameters, they are tailoredmade to scan logs on an industry scale. They are nondestructive and applied to sawn trees before they enter the processing phase. Scanning provides a 3D model of a specific cut and gives information about knots, piths and splits. Optimization software evaluates the acquired data.

Predecessors of such scanners are tomography scanners used in medicine since 1972 (Ulzheimer \& Flohr 2009). The technology has been significantly improved and perfected in the last years. Naturally, there are tendencies to implement computed tomography also to other-mainly industrial-areas. They are used to control rocket and jet engines as well as to produce specialised components (Bossi et al. 1991). If such technology is to be used in wood processing industry, it is necessary to solve several questions regarding health and safety, radiation, automatization, feed rate, stability and reliability when operating in dusty environment, area with vibrations and in bad weather conditions. Efficiency and size of the whole system is also important. These issues have been dealt with by several authors:

At the present time research and development of defects detection is focused on the improvement of algorithms and making their identification faster. Moreover, the technology of parallel processing is used. (Thomas \& Thomas 2013). Revised algorithm processes data with higher resolution and in shorter period. Higher performance means better analysis and results in more accurate detection of defects.

Thawornwong et al. (2003) analysed the application of gattered data from CT scanner in terms of its distinction. Three-dimensional resolution is a result number of total pixels, scan thickness and scan frequency. It is possible to use relatively thick scanning (3.1 megapixels, scanning thickness $5 \mathrm{~mm}$ ) without significant decrease in profit maximization.

Further automation of defects detection is depended on gathered results of tested algorithms. Brening (2014) 
deals with the evaluation accuracy reached in automatized knot detections. Error in the knot size has the biggest influence on yield maximization. On the other hand, inaccuracy in the knot position had insignificant influence. Author also studied the connection between appearance of wooden surfaces created by software optimization and human perception of such appearance. He concluded that created models correspond to the human perception of appearance.

Computed tomography to determine the a wood density (Freyburger et al. 2009) is used in modern scanners. Their research focused on the correlation between the Hounsfield scale and wood density. Calibration data set consisted of tropical wood samples representing a large range of densities ranging between $133 \mathrm{~kg} \cdot \mathrm{m}^{-3}$ and $1319 \mathrm{~kg} . \mathrm{m}^{-3}$ and was then validated using an independent data set (mainly temperate tree species). Achieved correlation was 0.999 .

Krähenbühl et al. (2012) dealt with the knot detection in 3D tomography images. They proposed an algorithm aimed at automatic detection and subsequend analysis of knots based on determining histograms of scanned log images. That is the difference of the standard algotithms based on deformation models. CT Log scanners Microtec has been the most often used in sawmills over the last years.

Implementation of CT scanners into industry was prevented in the past by several issues: (a) the need for high computational power of GPU processors in the utilization of integrative algorithm that provides high quality resolution; (b) complexity of sensor fields and the need for high power of Röntgen radiation that would be able to pass through thick logs; (c) securing resilience of rotating a very large gantry at the speed of $180 \mathrm{rpm}$. These technological problems were solved. Leaders are CT log scanners Microtec (Giudiceandrea et al. 2011), which have been gradually implemented into sawmills in the last years.

\subsection{Operational principles of CT Log Scanner parameters}

When scanning logs it is necessary to use technology of spiral tomography. Scanning consists of several steps: scanned object continuously slides into circular orbit source, on one side there is a source of X-ray and on the other side a set of detectors. Each point in a cut is given its own value of ray absorption according to the computed process (Fig. 1). According to the value of absorption, this value is transformed into the image and visualised in shades of grey. The acquired data are then used to reconstruct cuts in required places. The relationship between the length of shift in one rotation and thickness of cut is referred to as pitch. Higher the value is, the more of the scanned object can be covered, but at the same time quality of the resulting image decreases (Fig. 2).

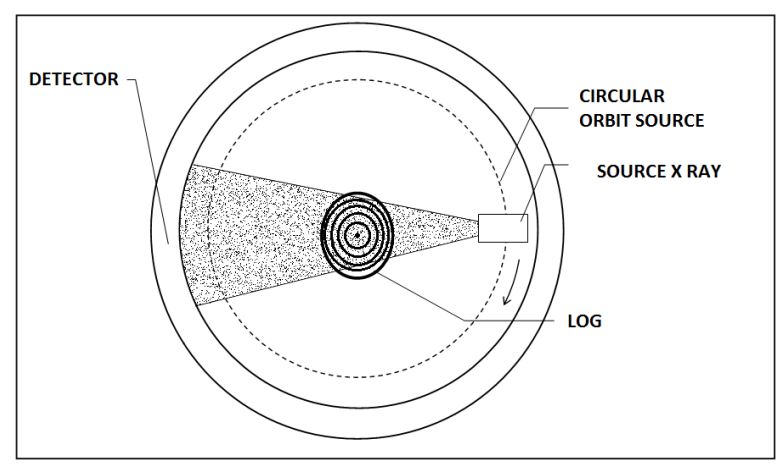

Fig. 1. Principle of scanning logs.

CT scanner is usually located in standard 20ft shipping container. Entering and exiting of a log is provided by conveyor belts. Length of logs is usually limited to $10 \mathrm{~m}$, but theoretically is unlimited. Maximum feed rate is $60 \mathrm{~m} / \mathrm{min}$. Diameter of a log is limited to $650 \mathrm{~mm}$ for softwood and $550 \mathrm{~mm}$ for hardwood. Operating temperature ranges from -30 to $45^{\circ} \mathrm{C}$ (Gazo \& Chang 2010).

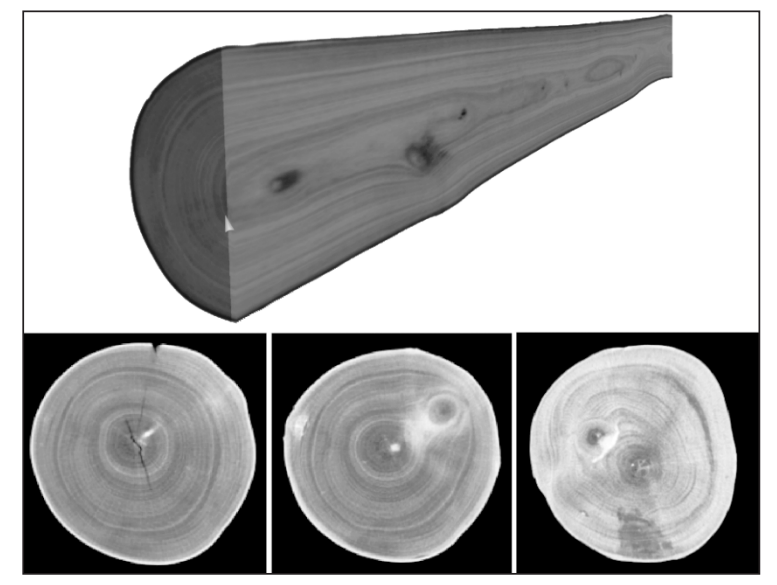

Fig. 2. 3D scanned model of a log and its cross sections.

$\mathrm{X}$-ray tube is a source of radiation. Therefore, employees and environment have to be protected according to the legislation of the country where it is installed. Dosage in the vicinity of such device is under the limit of $10 \mu \mathrm{Sv} / \mathrm{h}$. This value is guaranteed in the distance of at least $0.1 \mathrm{~m}$ from the surface of the device. The device is secured by safety gates connected to the safety device range. If the safety zone is breached, the source of $\mathrm{X}$-rays will turn off.

\subsection{Economic return of using the $3 \mathrm{D} C \mathrm{CT}$ scanner}

Following the research results mentioned in (Table 2). Economic return of investment in the 3D CT scanner was proposed. Development of improved algorithms to detect wood defects and subsequent log pattern optimisation are results of using the scanners in the wood processing. 
That results in increased profit. The specific production conditions for the results of the authors are unknown. Mostly national standards or wood processing standards were used.

Table 2. Table of profits by various researches.

\begin{tabular}{lclc}
\hline Author of research & Year & \multicolumn{1}{c}{ Test set [pcs] } & Profits [\%] \\
\hline Fredriksson & 2015 & 47 pine & 11.3 \\
Rinnhofer et. al. & 2003 & 30 spruce & 23.7 \\
Skog & 2013 & 74 spruce & 18 \\
Stängle et. al & 2016 & 19 beech & 24 \\
Berglund et. al. & 2013 & 408 pine and spruce & 16 \\
Hodges & 1990 & - & 17.5 \\
Schmoldt & 2000 & 30 spruce & 18 \\
Anonymus & 2015 & Coniferous and non-coniferous & 8 \\
\hline
\end{tabular}

\section{Analysis of economic return of using the 3D CT scanner}

\subsection{Input model parameters}

- Costs associated the CT scanner implementations are based on the still existing technology MICROTEC Company. Total costs for installation are $€ 2.5$ million. The sum includes CT scanner, software license, delivery, assembly, 10 m conveyor belt, software support for 100 days and putting the device into service.

- Sawmill profitability - coniferous timber: Potential economic return at the investment was proposed in three models according to the extent of produced coniferous timber: small sawmills with timber production up to $50000 \mathrm{~m}^{3}$, middle sawmills with timber production up to $100000 \mathrm{~m}^{3}$ and large sawmills timber production up to $200000 \mathrm{~m}^{3}$.

- Sawmill profitability - broadleaf timber: Similarly, regarding the broadleaf timber, three models were divided as follows: small sawmills with timber production up to $5000 \mathrm{~m}^{3}$, middle sawmills with timber production up to $20000 \mathrm{~m}^{3}$, large sawmills with timber production up to $50000 \mathrm{~m}^{3}$,

Price-timber: The cost of coniferous timber - based on the market research - was set to $€ 163.51$ per $\mathrm{m}^{3}$ (National Forest Centre Newsletter, 2/2017). Based on the research (Table 2), it was concluded that implementation of CT log scanner increases valuation of coniferous logs by $15 \%$.

- The cost of broadleaf timber - based on the market research - was set to $€ 200$ per $\mathrm{m}^{3}$ (National Forest Centre Newsletter, 2/2017).

- Expected economic profit: Based on the research (Table 2), it was concluded that implementation of CT $\log$ scan increases valuation of coniferous $\log$ by $23 \%$. These values were used to calculate payback period. - In the calculation the value of gross margin is used. It consists of $16 \%$ in coniferous trees processing and $45 \%$ in broadleaf trees (FinStat, 2017). Income tax $25 \%$ (EU average) wasn't taken into account. After that, the expenses were subtracted.

Annual profit was calculated according to Hodges et al. (1990)

$$
A V I=\sum_{i=1}^{12} P_{i} \times S M \times V Y I
$$

where:

$A V I$ - Annual Value Increase,

$P i$ - Price of lumber grade $i$,

$S M$ - Mill size (annual output),

VYI - Percent value profit increase.

\subsection{Economic return assessment of investment in 3D CT scanner}

Economic return assessment of investment in 3D CT scanner are depicted in Fig. 3 and Fig. 4 according to their corresponding sawmills. Point where the curves cross with broken curve (costs for CT scanner) represents estimated payback period of the investment in years.

Wood processing industry is a sector with longer innovation cycle and therefore the acceptable payback period is 8 or even 10 years. The results show that investment into CT log scanner is profitable for middle and large sawmills. For large sawmills, the payback period ranges around 4 years and for middle sawmills 8 years - coniferous wood processing. Investment for small sawmills

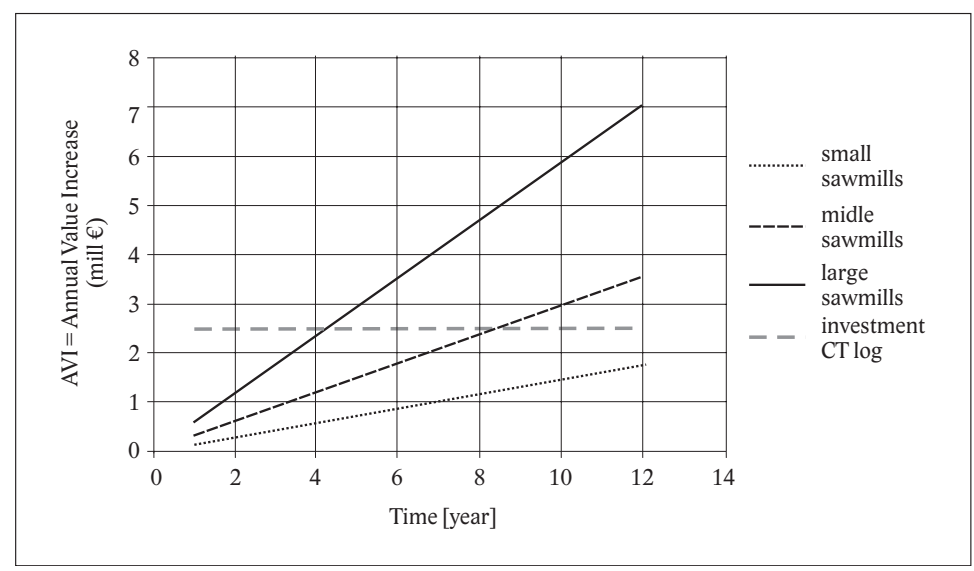

Fig. 3. Payback period of investments into CT scanner for small, middle and large sawmills (coniferous wood). 


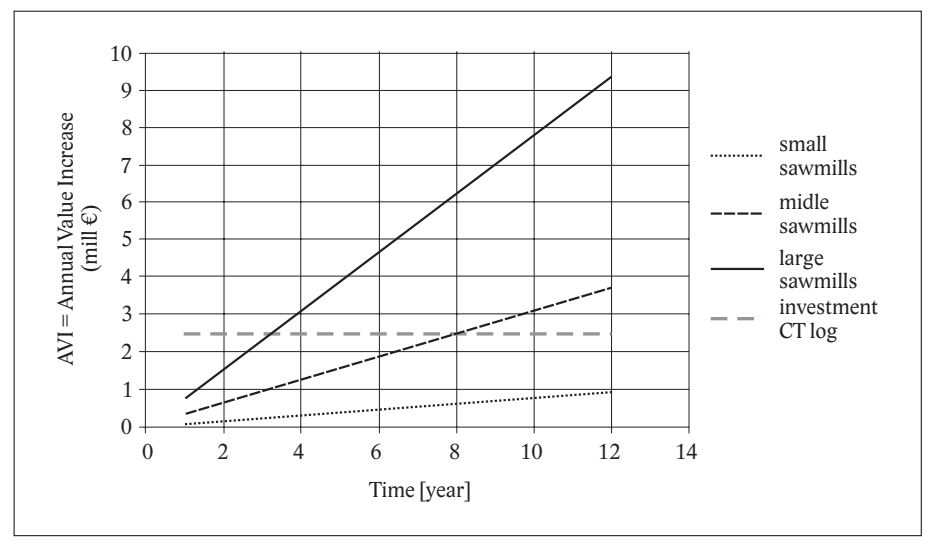

Fig. 4. Payback period of investments into CT scanner for small, middle and large sawmills (broadleaf wood).

would be profitable if the log value increased by $25 \%$.

Concerning processing of broadleaf trees, the investment into CT log scanner is also profitable for middle and large sawmills. Payback period for large sawmills is approximately 3 years and for middle sawmills 8 years. If the $\log$ value increased by $18 \%$, the investment into CT log scanner would be profitable for small sawmills as well - payback period approximately 10 years.

If there is a need to take into account income tax, it is necessary to multiply payback period by a coefficient 1.25. In this paper, this is neglected as write-offs theoretically effectively decrease the tax base during the payback period.

Cost efficiency of the use of CT log scanner expressed by the calculation of period of returns is necessary to enrich for other factors. A suitable tool is presented by SWOT analyze of CT scanner implementation in sawmill in the Slovakia which points at the factors which can influence the period of return positively or negatively (Table 3). The analysis shoes that the risk rate is relatively high. In the future to treats are possible to expect especially in securing disposable supply of coniferous logs and oak logs. On the contrary, there is sufficient amount of broadleaf wood (especially beech) and the presence of broadleaf wood species will increase in Slovak forests in the future. The CT scanning is even profitable for broadleaved wood species than for coniferous trees, it can mean an interesting opportunity and a competitive advantage on the market of processors. The change of market conditions is an assumption as customers mostly prefer coniferous timber in the present.

Human potential and its quality are also questionable, but training could prove helpful in various aspects (Vetráková et al. 2013; Hitka \& Balážová 2015). Motivation and education in this area are also important. Employees have to be acquainted with standards; they have to be able to evaluate qualitative features of logs, to effectively control the software and to take qualified steps in their corresponding positions (Lorincová et al. 2016).

\section{Prospect of log ct scanning for forestry and woodworking}

Implementation of intelligent technologies used to detect wood defects (CT for logs) and wood cutting (laser) into the wood-processing industry and their interconnection through information and communication technology provides a basis for a new concept - interconnection of the forestry-timber industries. In the following diagram (Fig. 5) the flow of raw material from producer to customer is displayed. Process flow and data flow in the forestry-woodprocessing sector are shown.

In green rectangles the process flow regarding intelligent technology in wood-processing industry can be seen. Blue rectangles represent innovation in forest man-

Table 3. SWOT analysis of CT logs scanner.

\begin{tabular}{lll}
\hline & \multicolumn{1}{c}{ Helpful } & Harmful \\
\hline \multirow{3}{*}{ Strengths } & Weaknesses \\
& - High-quality and available workforce. & - Need of trained personnel. \\
& - Long-term tradition of wood processing. & - Ignorance of market. \\
& - Regular customers. & - Weak companies infrastructure. \\
& Opportunities & - High investment costs. \\
\hline \multirow{5}{*}{ External origin } & - Potential of higher wood valuation (mainly of broadleaf logs). & Threats \\
& - Higher work productivity. & - Lnstable and specific market environment. \\
& - Reducing costs for workforce. & - Short-term contracts with suppliers. \\
& - Payback period for middle and large sawmills. & - Competition of the energetic sector. \\
& - Smaller amount of high-quality wood in future. & - Lower demand for broadleaf timber. \\
& - Extended settings for cutting plans optimisation. & - Higher level of automation in sawmill is needed. \\
& & - Complex connection of production process (hardware, software). \\
\hline
\end{tabular}




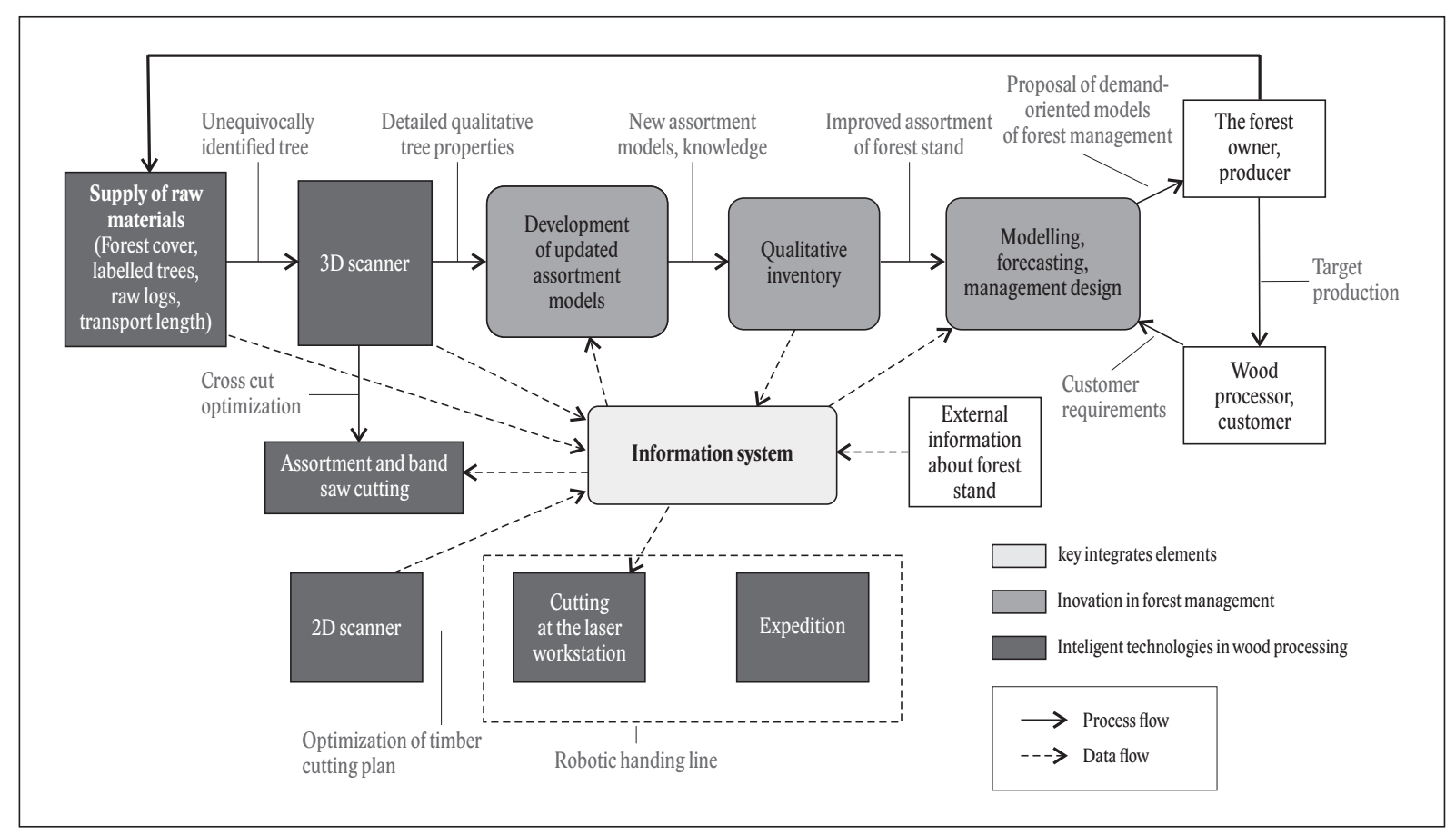

Fig. 5. Process flow and data flow in forestry- woodprocessing sector.

agement. These two flows are connected to a key integrating element - information systems (orange rectangle). The aim is to optimize the chain of production, delivery and processing of wood from cutting to dispatching individual products with outputs in following domains:

- Innovation in forest management focused on the most objective quality assessment of the wood produced

- Specifying tree assortment models in the area of internal wood defects detection by the use of 3D scanner and connection of information to information systems of wood producers

- Application of ICT technologies in the chain of production and wood-processing in the process of optimizing primary and secondary log breakdown

- Optimizing cutting plans for laser cutting

- Implementation and connectivity of new scanning technologies as well as laser cutting technologies with existing technologies on production line of manufacturers.

\section{Conclusions}

This paper utilizes acquired knowledge of existing researches conducted by foreign authors. It quantifies contributions of the CT scanner in the logs processing. All aforementioned researches show the increase of profit from processed wood ranging from $11.3 \%$ to $23.7 \%$ regarding coniferous logs. In terms of broadleaf $\log$, the profit increases by $24 \%$. Potential value of each $\log$ differs and it also depends on the current timber price.
Increase in the cost difference among individual wood grades means increase in the percentage of valuation. For the profitability verification in concrete conditions, for concrete sawmill, is the complex technological project needed.

The study is supplemented with SWOT analysis, which indicates the value at risk of implementing CT scanning technology into the production process on a relatively high level. The risk can be substantially decreased by the effective management. Such management can also create possibilities and considerable competitive advantages in the trade for both producers and manufacturers. If the wood-processing industry is to be competitive, if it is to effectively process raw material and to increase the quality of products, the implementation of CT scanning technology and new cutting technologies is necessary. Such technologies constitute essential innovation and they will bring the industry to the level of the technological leaders such as the car, industrial engineering and metal-working industries.

\section{Acknowledgment}

This work was supported by VEGA Nr. 1/0031/18 Optimization of technological and work processes and risk assessment in the production of forest biomass for energy purposes, MPRVSR item 08V0301 - Research and development to promote forestry competitiveness (SLOV - LES) and OPVaI International Teaming Research Centers. 


\section{References}

Anonymous, 2015: Microtec CT Log $360^{\circ} \mathrm{X}$-ray CT-Sawing Optimization. Microtec Innovating Wood. Available at: https://www.youtube.com/ watch? $\mathrm{v}=\mathrm{xK} 4 \mathrm{CdNT} 3 \mathrm{DK} 4$.

Berglund, A., Broman, O., Grönlund, A., Fredriksson, M., 2013: Improved log rotation using information from a computed tomography scanner. Computers and Electronics in Agriculture, 90:152-158.

Bossi, R. H., Knutson, B. W., Cline, J. L., Kruse, R. J., Georgeson, G. E., 1991: X-ray computed tomography for the aircraft/aerospace industry. In Review of progress in quantitative nondestructive evaluation. Springer, p. 2121-2127.

Breinig, L., 2014: CT log scanning for sawing optimization with regard to the aesthetic quality of wood. $\mathrm{PhD}$ thesis, University of Freiburg, p. 1-57.

Chernykh, V. L., Chernykh, D. V., Chernykh, L. V., Chernykh, E. N., 2014: Sortiment tables for estimation of artificial origin oak forests in the lower Volga region. Polythematic Online Scientific Journal of Kuban State Agrarian University, 95:1173-1190.

Danilović, M., Janjatović, G., 2005: Sortimentna struktura u zasadu topole populus x euramericana I-214 uz primenu Evropskih standarda kvaliteta, 91:97-109.

Fredriksson, M., 2015: Optimizing sawing of boards for furniture production using CT log scanning. Journal of Wood Science, 61:474-480.

Freyburger, C., Longuetaud, F., Mothe, F., Constant, T., Leban, J.-M., 2009: Measuring wood density by means of X-ray computer tomography. Annals of forest science, 66:804-804.

Gazo, R., \& Chang, S. J., 2010: Hardwood Log CT Scanning-Proof of Concept. Paper presented at the International Convention of Society of Wood Science and Technology and United Nations Economic Commission for Europe, Geneva, 1:1-5.

Giudiceandrea, F., Ursella, E., Vicario, E., 2011: A high speed CT scanner for the sawmill industry. In: Proceedings of the 17 th International Non-Destructive Testing and Evaluation of Wood Symposium. Sopron, Hungary, University of West Hungary, p. 105-112.

Greppel, E., Paluš, H., Chudovský, D., Šulek, R., 2009: Zhodnotenie drevnej hmoty a marketingové riadenie. Zvolen, National Forest Centre, 148 p.

Halaj, J., 1990: Rubná zrelost' drevín. Bratislava, Príroda, $117 \mathrm{p}$.

Hitka, M., Balážová, Ž., 2015: The impact of age, education and seniority on motivation of employees. Business, Theory and practice, 16:113-120.

Hoadley, R. B., 2000: Understanding wood: a craftsman's guide to wood technology. Taunton press, $280 \mathrm{p}$.

Hodges, D. G., Anderson, W. C., McMillin, C. W., 1990: The economic potential of CT scanners for hardwood sawmills. Forest Products Journal, 40:65-69.
Kleine, M., 1986: Sortentafeln für Buche in Österreich. Centralblatt für das gesamte Forstwesen, 103:15-36.

Klement, I., Réh, R., Detvaj, J., 2010: Základné charakteristiky lesných drevín-Spracovanie drevnej suroviny v odvetví spracovania dreva. Zvolen, NLC, $82 \mathrm{p}$.

Krähenbūhl, A., Kerautret, B., Rennesson, I. D., Longuetaud, F., Mothe, F., 2012: Knot Detection in X-Ray CT Images of Wood. In: ISVC - 8th International Symposium on Visual Computing - 2012, Jul 2012, Rethymnon, Greece, 7432:209-218.

Kulcsar, V., 1965: Nyárállományok kitermelési értéke. Nutzungswert der Pappel bestände. Az Erdö, 12:540-545.

Lorincová, S., Hitka, M., Javorčíková, J., Čambál, M., Szabó, P., 2016: The Importance of Motivation Process of Senior Managers in Forestry and Woodprocessing Sector in Slovakia. BioResources, 11: 10339-10348.

Mahút, J., Réh, R., 1995: The achievement of world class manufacturing within the wood industry. Zvolen, Technická univerzita vo Zvolene, 66 p.

Mecko, J., Petráš, R., Nociar, V., 1993: Konštrukcia nových stromových sortimentačných tabuliek pre smrekovec, hrab a brezu. Lesnícky časopis, 39:115124.

Mecko, J., Petráš, R., Nociar, V., 1994: Sortimentačné tabulky pre smrekovec, hrab a brezu. Bratislava, Veda, 76 p.

Pařez, J., 1987: Sortimentační tabulky pro bukové a dubové porosty s kmeny různé kvality. Lesnictví, 33: 1075-1090.

Petráš, R., Halaj, J., Mecko, J., 1996: Sortimentačné rastové tabulky drevín. Bratislava, Slovak Academic Press, 252 p.

Petráš, R., Mecko, J., Nociar, V., 2007: Modely kvality surového dreva stromov topol'ových klonov. Lesnícky časopis - Forestry Journal, 53:83-97.

Petráš, R., Nociar, V., 1991: Sortimentačné tabul'ky hlavných drevín. Bratislava, Veda, 304 p.

Rinnhofer, A., Petutschnigg, A., Andreu, J.-P., 2003: Internal log scanning for optimizing breakdown. Computers and Electronics in Agriculture, 41:7-21.

Schmoldt, D. L., Scheinman, E., Rinnhofer, A., Occena, L. G., 2000: Internal log scanning: Research to reality. In: Proceedings of the Twenty-Eighth Annual Hardwood Symposium, p. 103-114.

Skog, J., 2013: New Forest Industry Production Systems Based on High-speed CT Scanning (CT-Pro) In: WoodWisdom-Net Research Programme Final Report, p. 1-17.

Sterba, H., 1983: Funktionsschemata der Sortentafeln für Fichte in Österreich. Forstliche Bundesversuchsanstalt, 152:63. 
Stängle, S. M., Brüchert, F., Heikkila, A., Usenius, T., Usenius, A., Sauter, U. H., 2016: Potentially increased sawmill yield from hardwoods using X-ray computed tomography for knot detection. Annals of Forest Science, 72:57-65.

Suchomel, J., Gejdoš, M., 2013:Výrobné chyby sortimentov surového dreva. Zvolen, $123 \mathrm{p}$.

Thawornwong, S., Occena, L. G., Schmoldt, D. L., 2003: Lumber value differences from reduced CT spatial resolution and simulated log sawing. Computers and Electronics in Agriculture, 41:23-43.

Thomas, R. E., Thomas, L., 2013: Using parallel computing methods to improve log surface defect detection methods. In: Proceedings, 18th International Nondestructive Testing and Evaluation of Wood Symposium, p. 196-205.
Ulzheimer, S., Flohr, T., 2009: Current Technology and Future Developments. Multislice CT, Springer, $p$. $1-23$.

Vetráková, M., Potkány, M., Hitka, M., 2013: Outsourcing of facility management. Ekonomie a Management, 1:80-92.

\section{Internet sources:}

Biatec LaserTechnology:http://www.biatecgroup.com/ nove-laserove-technologie/

Lignosilva Science-Business Summit: http://lignosilva. nlcsk.org/files/Science_Business_summit.pdf 